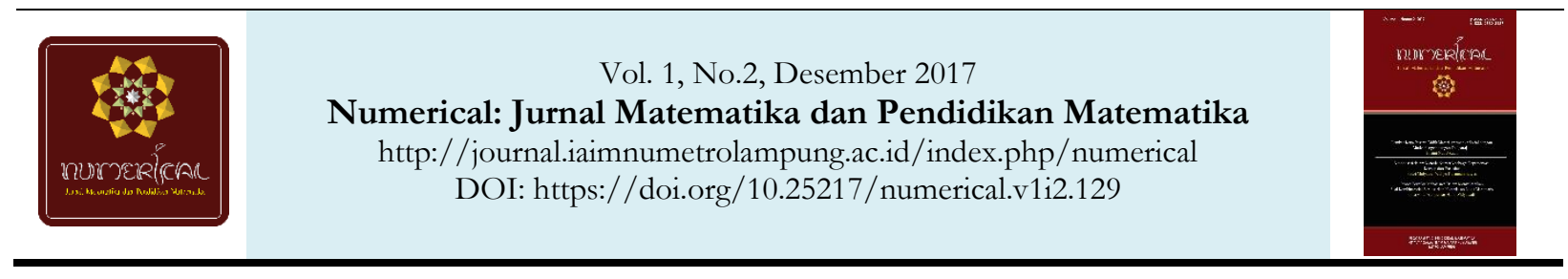

\title{
Simbolisasi dalam Metode Numerik sebagai Representasi Konsep dan Prosedur
}

\author{
Fauzi Mulyatna ${ }^{1}$ Wahyu Kusumaningtyas ${ }^{2}$
}

1) Universitas Indraprasta PGRI Jakarta, Indonesia

2) Institut Agama Islam Ma'arif NU (IAIMNU) Metro, Indonesia

Correspondence: $\square$ fauzimulyatna@gmail.com

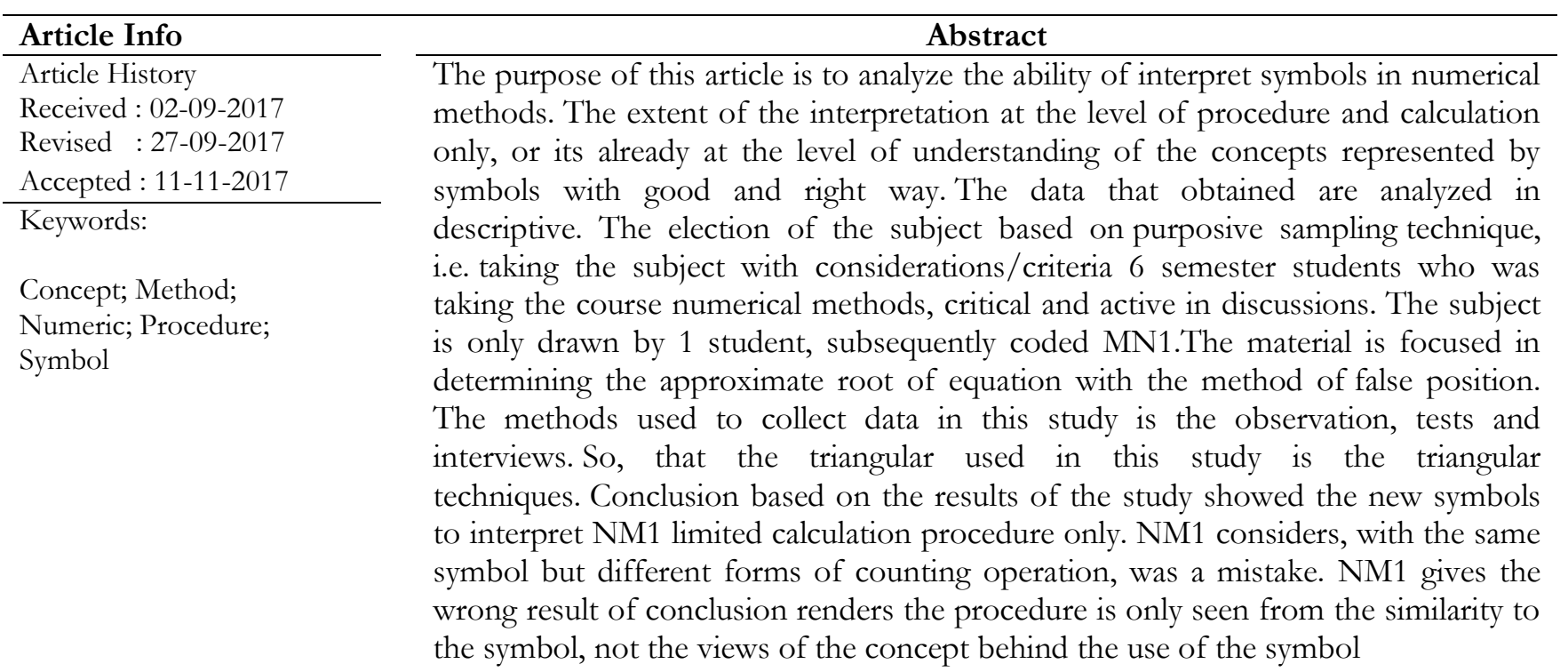

\section{PENDAHULUAN}

Pendidikan merupakan salah satu cara agar manusia memiliki kemampuan yang lebih baik [1]. Kemampuan berkomunikasi dengan baik adalah modal dasar untuk menjadi seorang guru. Calon guru dengan kemampuan akademik sangat pandai belum tentu menjadi guru yang baik bagi peserta didiknya jika tidak disertai dengan kemampuan komunikasi yang baik. Guru ideal akan terwujud jika latar belakang kemampuan akademik yang baik disertai kemampuan komunikasi yang baik pula.

Penyampaian informasi dapat berjalan dengan baik jika mengerti sekaligus paham maksud dan tujuan dari informasi yang disampaikan melalui komunikasi. Pembelajaran di kelas merupakan representasi komunikasi dua arah antara guru dan peserta didik. Masalah yang muncul adalah ketika informasi yang disampaikan guru tidak dapat dipahami sesuai maksud dan tujuan dari guru.

Begitu pula dalam pembelajaran matematika, informasi harus dapat disampaikan dengan baik. Sehingga komunikasi merupakan bagian yang penting dalam pembelajaran matematika. Sejalan dengan hasil penelitian [2], "communication is an essential part of mathematics education." Pandangan yang selama ini terbentuk dalam diri sebagian peserta didik bahwa matematika itu sulit turut menimbulkan hambatan dalam penyampaian informasi kepada peserta didik itu sendiri. 
Terlebih, pembelajaran matematika tidak akan pernah terlepas dari penggunaan simbol-simbol. Penting bagi peserta didik untuk mengetahui nama-nama simbol dalam matematika serta mengetahui konsep yang terwakili oleh simbol-simbol tersebut. Hal ini penting karena simbol yang hanya dibaca secara karakter huruf atau dipahami sebagai tekstual saja akan menimbulkan kesulitan bagi peserta didik.

Pentingnya simbol dalam matematika, sehingga mahasiswa maupun guru harus benar-benar paham konsepnya. Dalam hasil penelitian sebelumnya diperoleh bahwa dalam matematika notasi simbolis sebagai instrumen komunikasi dan pemikiran [3], "Mathematics makes use of symbolic notation, which serves a dual role as an instrument of communication and thought."

Sumber informasi yang beraneka ragam dan tidak terbatas memungkinkan peserta didik untuk mengakses sumber belajar dari berbagai media. Sumber belajar yang beranekaragam memunculkan kecenderungan perbedaan penulisan simbol dalam matematika. Kesulitan peserta didik muncul saat simbol-simbol yang telah dipelajari berbeda dengan simbol yang ditemukan dari sumber belajar lain di luar pembelajaran matematika di kelas.

Penting bagi guru untuk mengomunikasikan simbol-simbol sebagai keterwakilan dari konsep tertentu. Penting juga bagi guru untuk memberikan karakteristik simbol-simbol untuk mewakili konsepkonsep yang berbeda. Sehingga, guru sudah seharusnya tidak memahami simbol-simbol dalam matematika secara tekstual saja. Simbol tidak hanya dibaca secara karakter per karakter huruf saja. Berdasarkan hasil penelitian juga mengindikasikan permasalahan dalam penguasaan simbol matematika [4], "Many language challenges have contributed to dismal performance such as poor mastery of specialized mathematical symbols, use of terms that have different meanings, linguistic barrier that leads to poor communication in classrooms and language-based factors in solving mathematical word problems."

Universitas Indraprasta PGRI, khususnya Pendidikan Matematika salah satu luarannya adalah untuk mempersiapkan mahasiswanya menjadi calon guru yang profesional. Sehingga mahasiswa dalam setiap kegiatan perkuliahan di kelas perlu dipersiapkan dan dilatih untuk mengembangkan kemampuan komunikasi. Karena kemampuan komunikasi yang baik diawali dari pembiasaan. Komunikasi yang baik dilandasi dari kemampuan penguasaan materi yang ingin disampaikan oleh mahasiswa. Kemampuan tersebut akan tercapai jika mahasiswa memiliki kemampuan komunikasi matematis yang baik. Kemampuan komunikasi matematis merupakan kemampuan dalam menulis dan membaca simbol, menyajikan, menganalisis, dan menginterpretasikan data.

Kemampuan dalam menulis dan membaca simbol inilah kelemahan yang biasanya dialami mahasiswa. Berdasarkan hasil observasi dalam perkuliahan metode numerik, ditemukan beberapa permasalahan, kurang tepat dalam 1) menuliskan simbol; 2) menafsirkan symbol; dan 3) memberikan kesimpulan.

Permasalahan yang ditemukan dalam proses observasi sebenarnya berkaitan dengan kemampuan komunikasi matematis. Permasalahan komunikasi matematis yang bisa dijabarkan secara tertulis maupun secara lisan. Hal ini dapat menjadi kelemahan saat mahasiswa telah menjadi guru. Pembacaan dan penulisan simbol yang salah, berakibat tidak tersampaikannya ide dari masalah (konsep) secara optimal kepada peserta didik. Penyampaian yang tidak optimal membentuk pola pikir peserta didik yang salah konsep, miskonsepsi, maupun konsep yang tidak komplit.

Begitu juga penyajian data yang dilakukan oleh mahasiswa tidak sesuai dengan tujuan, maka akan terjadi kesalahan pemahaman dan interpretasi, sehingga berakibat pada ketidaktepatan informasi yang didapat dari penyajian data tersebut. Mahasiswa harus tahu letak permasalahan dari soal yang diberikan. Menjadi kesalahan yang tidak sepantasnya jika pengerjaan dengan prosedur yang benar tetapi pada 
akhirnya memperoleh jawaban yang salah hanya karena tidak tahu letak permasalahan. Dengan kata lain, tidak mengetahui letak permasalahan akan berakibat pada pengambilan kesimpulan yang kurang tepat. Dan hal ini merupakan fakta yang diperoleh dari hasil observasi. Pengambilan kesimpulan yang salah masih ditemukan dalam pekerjaan mahasiswa, padahal prosedur pengerjaan dan dengan perhitungan yang benar.

Pengambilan metode numerik sebagai materi penelitian dikarenakan melibatkan banyak simbol dalam perhitungannya. Di samping melibatkan aritmatika, berkaitan dengan angka dan operasi hitung, juga melibatkan aljabar, tetapi aljabar yang lebih difokuskan pada hubungan antara jumlah dan menggunakan bahasa simbolik atau variabel. Hal ini didasarkan pada pendapat Yunarni bahwa aljabar merupakan cabang penting dari matematika,yang sering dianggap sebagai pelajaran yang sulit dan abstrak [5].

Dalam penelitian lain, juga menguatkan aljabar menjadi salah satu kendala di dalam metode numerik. Kesulitan yang paling penting adalah kegagalan dalam memahami konsep variabel, dikemukakan oleh Akgun, "Experience of teachers and several experimental studies show that students have difficulties in understanding general arithmetic algebra. There are several conceptual obstacles in proceeding in algebra. And one of the most important difficulties is the failure in understanding the concept of variable." Konsep variabel erat kaitannya dengan penggunaan simbol. Simbol yang dapat mewakili penamaan atau konsep tertentu [6].

Di samping tujuan jangka panjang untuk mempersiapkan mahasiswa menjadi guru yang professional, mengetahui konsep dalam proses perhitungan merupakan dasar dalam pembentukan algoritma. Algoritma yang digunakan dalam program semisal Excel, Turbo Pascal, Fortran 77 hingga Matlab.

Eksekusi dalam pemrograman metode numerik harus dilandasi dengan algoritma yang jelas agar sintaks dapat berjalan atau tidak memunculkan error. Algoritma pun harus didasari konsep yang benar sehingga hasilnya dapat diperoleh aproksimasi yang akurat dan valid.

Di sisi lain, pemahaman matematis memiliki peranan yang penting. Pemahaman matematis adalah sentral dari pembelajaran matematika sekolah. Sehingga mahasiswa sebagai calon guru, perlu dibiasakan untuk digali pemahaman konsepnya, tidak hanya sekedar penilaian di atas kertas saja [7]. Kecenderungan yang ada adalah mahasiswa tidak begitu mengerti maksud dari tulisannya sendiri. Mahasiswa hanya menjawab atau menuliskan berdasarkan pengalaman sebelumnya. Mencari solusi dari permasalahan hanya berdasarkan prosedur ataupun langkah-langkah perhitungan yang sudah ada. Proses berfikir dalam menyelesaikan masalah yang cenderung prosedural tanpa memerlukan ide-ide kreatif termasuk dalam proses berfikir konvergen [8].

Pembiasaan dari pengerjaan soal hanya berdasar contoh yang sudah ada menyebabkan pemahaman matematis mahasiswa tidak berkembang. Permasalahan ini juga ditemui dalam observasi. Konteks permasalahan yang berbeda, tetapi mahasiswa menyelesaiakan permasalahan hanya melihat pada contoh prosedur/langkah-langkah perhitungan yang sudah ada. Kesimpulan yang diperoleh menghasilkan solusi yang kurang tepat, kurang valid bahkan menjadi salah. Inilah salah satu dampak dari memahami simbol hanya sebatas pada langkah perhitungan saja, hanya sebatas prosedur saja.

Dengan adanya beberapa permasalahan yang berkaitan dengan simbol dalam metode numerik dan akibat yang ditimbulkan, perlu digali lebih mendalam tentang kemampuan mahasiswa dalam membaca simbol, menuliskan simbol, menggunakan simbol, menyajikan informasi yang berkaitan dengan keterwakilan konsep oleh simbol dan kemampuan menginterpretasikan hasil akhir yang berupa 
kesimpulan. Jika kemampuan penulisan simbol, pembacaan simbol, serta yang tidak kalah pentingnya adalah pemahaman tentang keterwakilan konsep dengan simbol, maka proses penyampaian informasi dari permasalahan yang ada akan semakin optimal. Berdasarkan permasalahan tersebut, peneliti ingin melihat lebih dalam tentang kemampuan mahasiswa menginterpretasikan simbol dalam metode numerik. Interpretasi yang sebatas pada tingkat prosedur dan perhitungan saja, atau sudah pada tingkat memahami konsep yang terwakili oleh simbol dengan baik dan benar.

\section{METODE}

Penelitian ini dilaksanakan di Universitas Indraprasta PGRI Jakarta pada semester genap tahun akademik 2016/2017. Alamat Kampus B: Jl. Raya Tengah No. 80, Kel. Gedong, Kec. Pasar Rebo, Jakarta Timur 13760. Sedangkan proses/jangka waktu penelitian pada bulan Juni-Agustus 2017.

Jenis penelitian ini adalah penelitian kualitatif. Data yang diperoleh kemudian dianalisis secara deskriptif [9], "The rich descriptions provided by qualitative research are often instrumental in belping readers understand the relationship between the context of a given study and their own circumstances."

Metode kualitatif digunakan untuk mendapatkan data yang mendalam, suatu data yang mengandung makna [10]. Dalam penelitian ini yang dimaksud data yang mendalam adalah data tentang analisis kemampuan mahasiswa menginterpretasikan simbol dalam metode numerik. Interpretasi yang sebatas pada tingkat prosedur dan perhitungan saja, atau sudah pada tingkat memahami konsep yang terwakili oleh simbol dengan baik dan benar.

Subjek merupakan mahasiswa pendidikan matematika. Dalam penelitian ini pemilihan subjek berdasarkan teknik purposive sampling. Purposive sampling adalah teknik pengambilan subjek sumber data dengan pertimbangan/kriteria tertentu. Kriteria pemilihan subjek utama penelitian adalah mahasiswa semester 6 yang sedang mengambil mata kuliah metode numerik, kritis dan aktif dalam diskusi. Subjek hanya diambil 1 mahasiswa, selanjutnya diberi kode MN1.

Data utama penelitian ini berupa hasil obervasi pembelajaran di kelas, analisis tes tertulis dan wawancara [11]. in qualitative research, interviewing, observations and document analysis are the major source of the qualitative data for understanding the phenomenon under study.

Metode yang digunakan untuk mengumpulkan data dalam penelitian ini adalah observasi, tes dan wawancara. Observasi dilakukan dengan subjek yang dikondisikan dalam suasana pembelajaran di kelas. Pembelajaran yang menggunakan metode diskusi, sehingga dapat terlihat respon awal subjek dalam menerima konsep. Tes dalam penelitian ini adalah tes tertulis berbentuk uraian.

Sedangkan wawancara diperlukan untuk mengetahui pemahaman subjek terhadap konsep dalam penggunaan simbol. Materi wawancara juga mengacu pada hasil pemikiran subjek dalam observasi dan tes. Dengan kata lain, wawancara merupakan metode untuk mengetahui pemikiran/pendapat subjek, [11], "The interview method takes the form of a dialogue in which the researcher seeks to elicit information from the subject about how the latter thinks." bahwa suasana wawancara yang santai merupakan aspek yang penting, "Important aspects in interviews include maintaining a relaxed manner, asking clear questions, note-taking, appropriate use of follow-up question or probes, establishing trust, and keeping track of responses." Dan suasana nyaman, santai, benar-benar diterapkan dalam proses wawancara subjek penelitian ini.

Instrumen dalam penelitian ini terdiri dari peneliti sebagai instrumen utama serta catatan lapangan untuk proses observasi, soal tes uraian, dan pedoman wawancara sebagi instrumen bantu. Teknik pemeriksaan keabsahan data (validitas) dilakukan setelah memperoleh data dari subjek penelitian. Data yang dimaksud dalam penelitian ini adalah hasil analisis observasi subjek dalam proses pembelajaran, 
hasil tes uraian dan hasil analisis wawancara. Sehingga triangulasi yang digunakan dalam penelitian ini adalah triangulasi teknik.

Validitas data akan menunjukkan bahwa yang disajikan peneliti sesuai dengan kondisi yang sebenarnya dalam hal ini adalah kemampuan mahasiswa menginterpretasikan simbol dalam metode numerik, interpretasi yang sebatas pada tingkat prosedur dan perhitungan saja, atau sudah pada tingkat memahami konsep yang terwakili oleh simbol dengan baik dan benar. Teknik analisis data yang dilakukan melalui reduksi data, display data, verifikasi dan mengambil kesimpulan.

\section{HASIL DAN PEMBAHASAN}

Data dalam penelitian diperoleh dari observasi pada proses pembelajaran di kelas, hasil tes tertulis dan hasil wawancara dengan subjek penelitian.

\section{Proses Pembelajaran di Kelas}

Perkuliahan di kelas yang melibatkan subjek, dilakukan dengan metode diskusi. Pemilihan metode diskusi didasarkan pada hasil penelitian [12] bahwa dosen/guru dapat memberikan kesempatan berkomunikasi secara lisan akan memberi peluang untuk mengetahui apa yang belum diketahui mahasiswa atau konsep mana yang masih perlu dijelaskan. Metode diskusi dalam penelitian ini memberikan ruang bagi subjek untuk menyampaikan gagasannya sekaligus memberikan ruang bagi peneliti untuk memperoleh informasi/data. Materi yang menjadi fokus penelitian adalah metode false position. Materi inilah yang menjadi pokok bahasan dalam diskusi.

Konsep yang dipakai dalam metode false position merupakan aproksimasi/nilai pendekatan penentuan solusi akar persamaan dengan bantuan garis yang melalui 2 titik dari grafik sehingga memotong sumbu $x$. Hal inilah yang menjadi bahan diskusi dalam proses pembelajaran/perkuliahan metode numerik.

Metode false position menggunakan dua nilai interval (dalam Gambar 1 yaitu $a$ dan $b$ ) di antara nilai solusi akar persamaan yang memiliki tanda berlainan $(f(x)>0$ dan $f(x)<0)$. Jadi dengan interval awal $[a, b]$ dimana $f(x)$ adalah kontinu padanya, demikian pula interval tersebut harus terletak 'mengapit' (secara intuitif) nilai akar $\alpha$, sedemikian rupa sehingga,

$$
f(a) \times f(b) \leq 0
$$

Iterasi pada metode false position dengan pencarian nilai diantara interval pertama, yang dicari dengan menarik garis lurus antara $(a, f(a))$ dan $(b, f(b))$, serta mengambil nilai $c$ (nilai di antara $a$ dan $b)$ dari perpotongan garis $P Q$ dengan sumbu $x$.

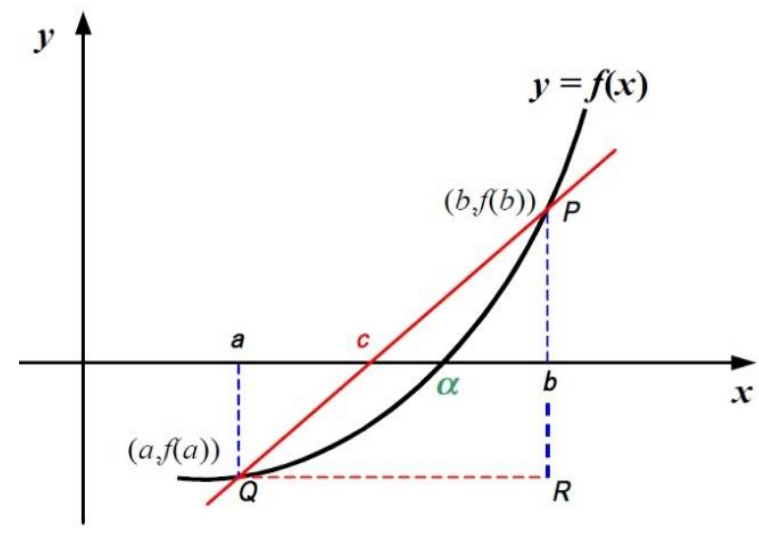

Copyright (C) 2017, Numerical: Jurnal Matematika dan Pendidikan Matematika Print ISSN: 2580-3573, Online ISSN: 2580-2437 


\section{Gambar 1. Grafik Penentuan Akar Persamaan dengan Metode False Position}

Ada dua konsep yang bisa digunakan untuk mendasari proses iterasi dalam metode false position, yaitu konsep kesebangunan dan konsep persamaan garis.

Konsep kesebangunan diperoleh dari 2 segitiga, yaitu $\triangle P c b$ dan $\triangle P Q R$ (perhatikan Gambar 1.). Sehingga bisa dituliskan dalam persamaan:

$$
\frac{P b}{b c}=\frac{P R}{R Q}
$$

Berdasarkan nilai grafik $f(x)$-nya,

$$
\frac{f(b)-0}{b-c}=\frac{f(b)-f(a)}{b-a}
$$

Formula yang digunakan untuk proses iterasi,

$$
c=b-f(b) \frac{b-a}{f(b)-f(a)} \cdots(i)
$$

Melalui konsep persamaan garis yang melalui 2 titik $(a, f(a))$ dan $(b, f(b))$, diperoleh:

$$
\frac{x-a}{b-a}=\frac{y-f(a)}{f(b)-f(a)}
$$

Titik $c$ diperoleh saat $y=0$, atau dituliskan dalam pasangan koorinat menjadi $(c, 0)$. Kemudian disubtitusikan ke dalam persamaan garis menjadi,

$$
\frac{c-a}{b-a}=\frac{0-f(a)}{f(b)-f(a)}
$$

Formula yang digunakan untuk proses iterasi,

$$
c=a-f(a) \frac{b-a}{f(b)-f(a)} \cdots
$$

Bisa juga diperoleh persamaan garis

$$
\frac{x-b}{a-b}=\frac{y-f(b)}{f(a)-f(b)}
$$

Sehingga formula iterasi yang digunakan pun akan berubah menjadi,

$$
c=b-f(b) \frac{a-b}{f(a)-f(b)} \cdots(i i i)
$$

Pada saat proses diskusi, subjek (MN1) memberikan argumen bahwa bentuk persamaan (iii) salah. Bentuk persamaan

$$
c=b-f(b) \frac{a-b}{f(a)-f(b)}
$$

tidak tepat digunakan dalam formula iterasi metode false position.

Bentuk yang benar adalah persamaan( $i i)$,

$$
c=a-f(a) \frac{b-a}{f(b)-f(a)}
$$

Karena asal mulanya diperoleh dari persamaan garis yang terbentuk dari

$$
\frac{x-x_{1}}{x_{2}-x_{1}}=\frac{y-y_{1}}{y_{2}-y_{1}}
$$


Hasil analisis dari proses pembelajaran yang diikuti oleh MN1, mengindikasikan MN1 memahami simbol baru sebatas prosedural dalam proses perhitungan saja. MN1 juga terindikasi mengidentikan penamaan simbol selalu didasarkan pada urutan abjad atau urutan angka. Hal ini mengacu pada pengalaman pertama MN1 dalam menerima konsep persamaan garis. Dengan kata lain, persamaan

$$
\frac{x-x_{1}}{x_{2}-x_{1}}=\frac{y-y_{1}}{y_{2}-y_{1}}
$$

oleh subjek diidentikan bahwa harus $x_{1}$ merupakan absis untuk $a, x_{2}$ merupakan absis untuk $b$. Begitu pula untuk ordinatnya, $y_{1}$ merupakan ordinat untuk $f(a)$ dan $y_{2}$ merupakan ordinat untuk $f(b)$. MN1 memberikan pemahaman urutannya tidak boleh terbalik.

Dari proses pembelajaran inilah, MN1 terindikasi memahami simbol baru sebatas tingkat prosedur saja, representasi simbol yang dipahami oleh MN1 baru sebatas tingkat prosedural.

\section{Hasil Tes Tertulis}

Tes tertulis berbentuk uraian diberikan kepada MN1 untuk mengetahui kemampuan dalam menyerap pengetahuan dari proses pembelajaran di kelas. Soal uraian yang diberikan sebanyak 2 buah, sebagai berikut, 1) Gunakan metode false position untuk menentukan hampiran akar $f(x)=e^{x}-4 x$ pada interval $[0,1]$ dengan $\varepsilon=0,01$, hingga 4 angka signifikan, 2) tentukan nilai hampiran akar $p(x)=$ $x^{3}-x^{2}+2 x-1$ menggunakan metode false position pada selang [0,1] dengan $\varepsilon=0,03$ dan pembulatan hingga 3 angka signifikan.

Berdasarkan hasil jawaban no.1 dari NM1, menunjukkan perulangan simbolisasi $f(a) \times f(c)$ dalam langkah-langkah awal perhitungan (iterasi 1-3) yang selalu bernilai $<0$, memberikan pemahaman konsep yang keliru oleh NM1. Pada iterasi 4, berdasarkan nilai $f(a) \times f(c)>0$, NM1 menghentikan proses iterasi. Padahal konsepsi yang benar, proses iterasi berhenti bukan atas dasar itu, melainkan jika nilai $f(c)=0$ atau berdasarkan galat relatifnya $\leq \varepsilon$. Untuk lebih jelasnya, berikut ini hasil jawaban MN1 pada iterasi 1-4 soal nomor 1, pada Gambar2., Gambar 3., Gambar 4., dan Gambar 5.

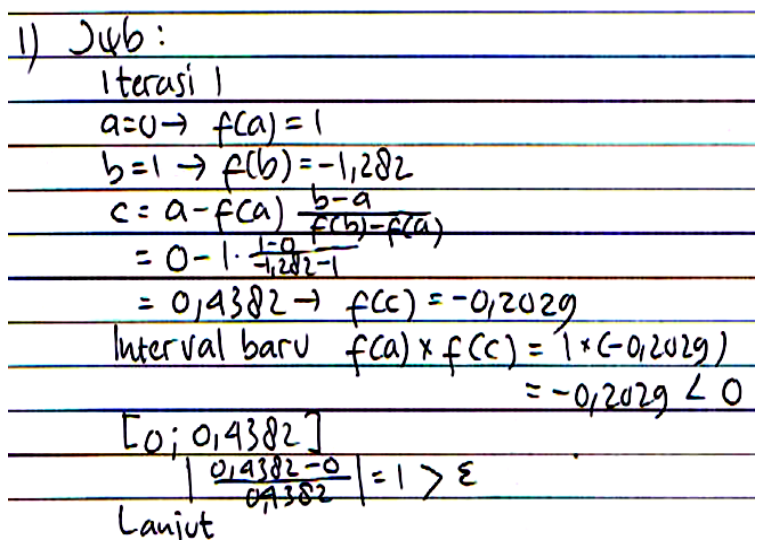

Gambar 2. Hasil Jawaban Tertulis MN1 pada Iterasi 1 Soal Nomor 1 
Numerical: Jurnal Matematika dan Pendidikan Matematika, Vol. 1 No. 2 Desember 2017, 73-86

Fauzi Mulyatna, Wahyu Kusumaningtyas

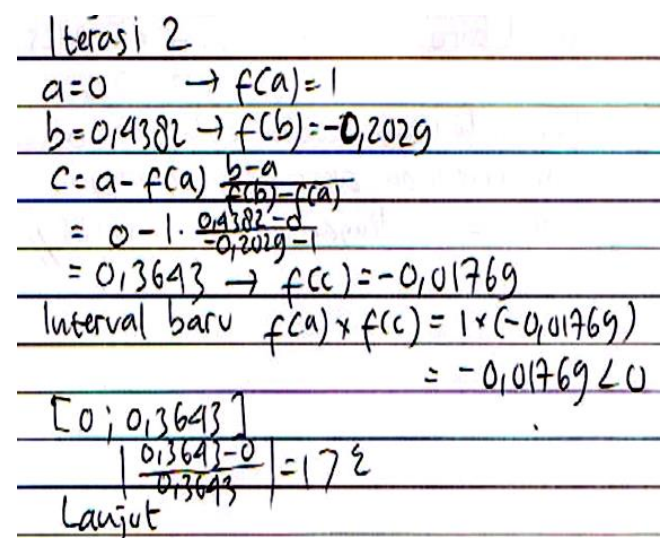

Gambar 3. Hasil Jawaban Tertulis MN1 pada Iterasi 2 Soal Nomor 1

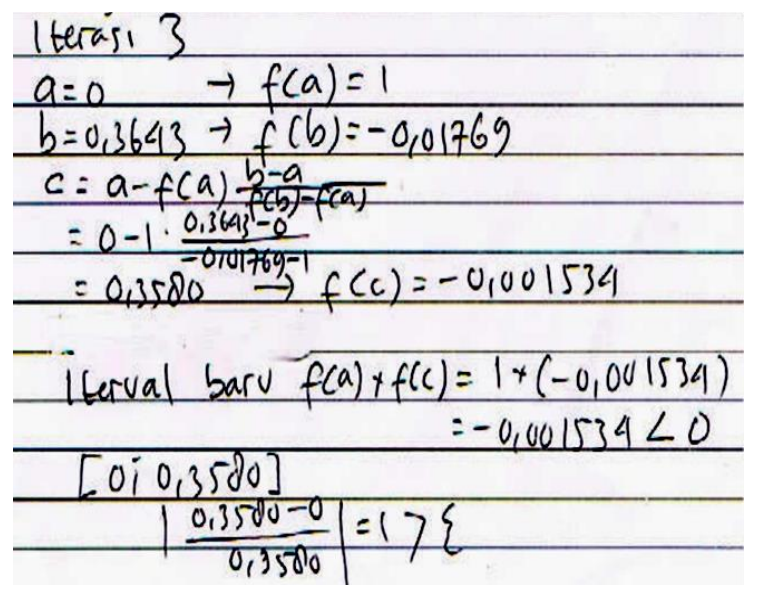

Gambar 4. Hasil Jawaban Tertulis MN1 pada Iterasi 3 Soal Nomor 1

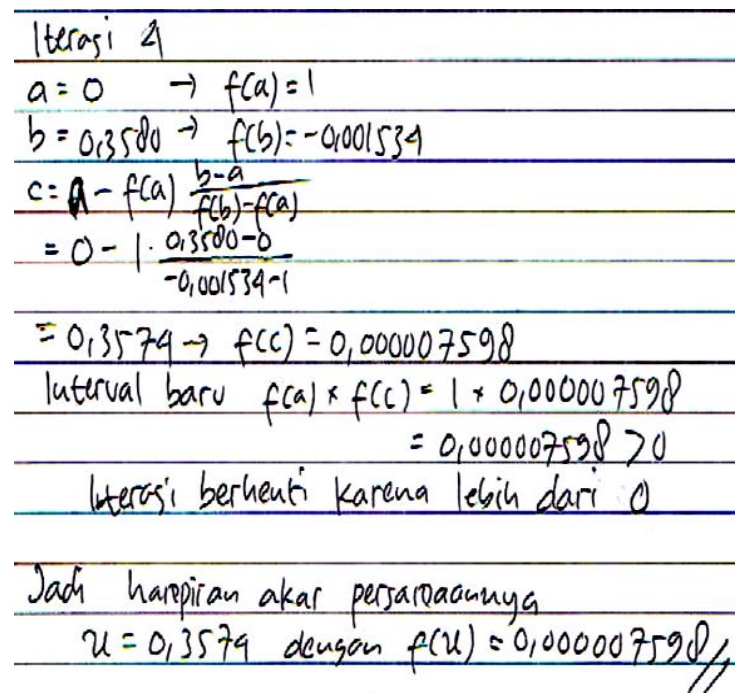

Gambar 5. Hasil Jawaban Tertulis MN1 pada Iterasi 4 Soal Nomor 1

Hal ini menimbulkan permasalahan jika instrumen tes yang diberikan berbentuk pilihan ganda. Pada soal no.1, kebetulan iterasi 4 proses perhitungan berhenti, tetapi alasan berhentinya karena galat relatif, yaitu $\left|\frac{0,3580-0,3574}{0,3580}\right|=0,001676$ lebih kecil dari nilai $\varepsilon=0,01$. Walaupun dengan kesimpulan 
yang benar, tetapi ada proses yang salah. Hal ini bisa menjadi kesalahan yang tidak terdeteksi, MN1 merasa benar, karena memang kesimpulan akhirnya juga benar. Indikasi ini menunjukkan MN1 hanya memahami simbol hanya sebatas prosedur saja. Prosedur yang dimaknai oleh MN1 sebagai perulangan perlakuan yang sama.

Hasil jawaban no.2 menguatkan indikasi bahwa MN1 hanya memahami simbol hanya sebatas prosedur dalam perhitungan saja. Pada proses pengambilan interval yang baru, selalu menyertakan $f(a) \times f(c)$. Nilai $f(a) \times f(c)$ yang berbeda $(>0)$, mengakibatkan pemahaman MN1 mengehentikan iterasi, karena interval baru tidak memenuhi syarat. Padahal jika simbol itu dimaknai sebagai keterwakilan dari konsep bahwa interval harus terletak 'mengapit' (secara intuitif) nilai akar persamaan, maka MN1 seharusnya mengambil nilai $f(b) \times f(c)<0$ sebagai prasyarat penentuan interval baru pada proses iterasi berikutnya.

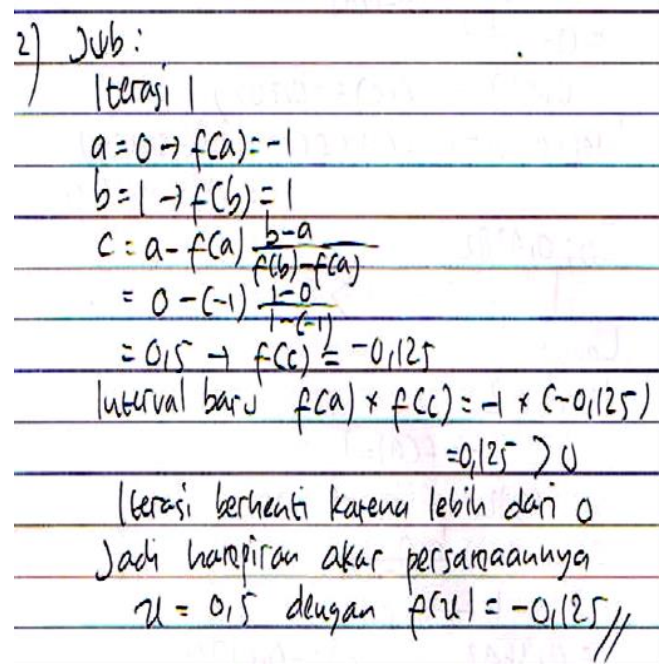

Gambar 6. Hasil Jawaban Tertulis MN1 pada Iterasi 1 Soal Nomor 2

Hasil jawaban tertulis MN1 pada nomor 2 menunjukkan bahwa perulangan simbol yang sama menjadi generalisasi untuk prosedur perhitungan.

Jadi berdasarkan analisis hasil jawaban tes tertulis, MN1 menginterpretasikan simbol baru sebatas prosedur perhitungan saja. NM1 menuliskan prosedur hanya dilihat dari kesamaan simbol, tidak dilihat dari konsep yang melatar belakangi penggunaan simbol tersebut. Proses generalisasi yang dilakukan MN1 dalam prosedur perhitungan hanya sebatas melihat dari kesamaan simbol.

\section{Hasil Wawancara}

Wawancara diperlukan untuk memperdalam data temuan awal dari observasi pembelajaran di kelas dan hasil tes tertulis. Memperdalam temuan awal ini adalah untuk menguatkan hasil analisis observasi pada proses pembelajaran di kelas maupun analisis hasil tes tertulis, menglarifikasi atau bahkan memunculkan temuan baru.

Berdasarkan hasil wawancara, MN1 belum memahami dengan benar konsep penggunaan metode false position dalam menentukan nilai akar persamaan.

Berikut ini kutipan script wawancara yang menunjukkan keadaan tersebut.

P : Yang Anda pikirkan dari metode false position itu apa? Tujuan akhirnya itu untuk apa?

NM1 : Ya tu lho Pak, nyari akar persamaan 
P : Kamu tahunya akar persamaan udah ketemu gimana coba? Konsepnya seperti apa?

NM1 : Setahu saya Pak, kalo udah lebih kecil dari $\varepsilon$

P : : Oh gitu ya... Baiklah

Ok, sekarang yang kamu kerjain kemarin, kok udah berhenti, padahal tidak kamu tunjukkan nilai $\varepsilon$ ?

NM1 : Eh iya Pak... Iya...

Itu juga yang mau saya omongin, lupa... Tu juga udah berhenti Pak, kan $f(a) \times f(c)>0$.

Berarti udah gak ada interval baru lagi dong, sama aja berhenti kan Pak, ya gak sich Pak?

Hasil script wawancara menunjukkan MN1 hanya terpaku pada simbol dalam prosedur perhitungan, sehingga menimbulkan pemahaman konsep yang keliru dalam proses perhitungan itu sendiri. Bukan hanya itu, konsep dasarnya pun menjadi kurang tepat, karena MN1 hanya terpaku pada masalah perhitungannya saja, terlepas dari penggunaan simbolnya.

Konsep dasar dari penentuan akar persamaan dengan metode false position sebenarnya mencari nilai pembuat nol fungsi. Hasil akhir yang diharapkan adalah memperoleh nilai $x$ sedemikian hingga nilai fungsinya adalah nol. Jika itu terlalu panjang prosesnya, maka diambil nilai pendekatannya (aproksimasi) karena yang dibahas dalam penelitian ini adalah proses perhitungan secara manual dalam metode numerik. Oleh sebab itu ditentukan nilai $\varepsilon$ sebagai acuan untuk menentukan proses iterasi berhenti.

Proses perhitungan yang dilakukan oleh NM1 juga hanya terpaku pada formula dengan simbol yang sama. NM1 belum memahami konsep yang terwakili oleh simbol, sehingga pada formula/rumus perhitungan yang berbeda oleh NM1 dianggap salah.

Berikut ini kutipan script wawancara yang menunjukkan keadaan tersebut.

$\mathrm{P} \quad$ : Dalam menentukan $c$ formula atau rumus mana yang kamu gunain?

NM1 : Ini Pak rumusnya,

P : :Harus kayak gitu ya bentuk rumusnya?

$$
c=a-f(a) \frac{b-a}{f(b)-f(a)}
$$

NM1 :Iya Pak, kan itu asal mula dari rumus garis lurus. Kalo kebalik ato gak sama ya salah dong Pak.

P : :Oh gitu ya... Baiklah

Sekarang coba, di nomor 1, coba kamu hitung untuk iterasi 1 aja, dengan macam-macam rumus ato formula ini

$$
\begin{aligned}
c & =b-f(b) \frac{a-b}{f(a)-f(b)} \\
c & =b-f(b) \frac{b-a}{f(b)-f(a)} \\
c & =a-f(a) \frac{b-a}{f(b)-f(a)}
\end{aligned}
$$

NM1 :Baik Pak...

(kemudian NM1 mengerjakan kembali iterasi 1 pada soal nomor 1 dengan berbagai macam formula/rumus)

Hasilnya sama Pak (sambil menunjukkan hasil pekerjaannya) 


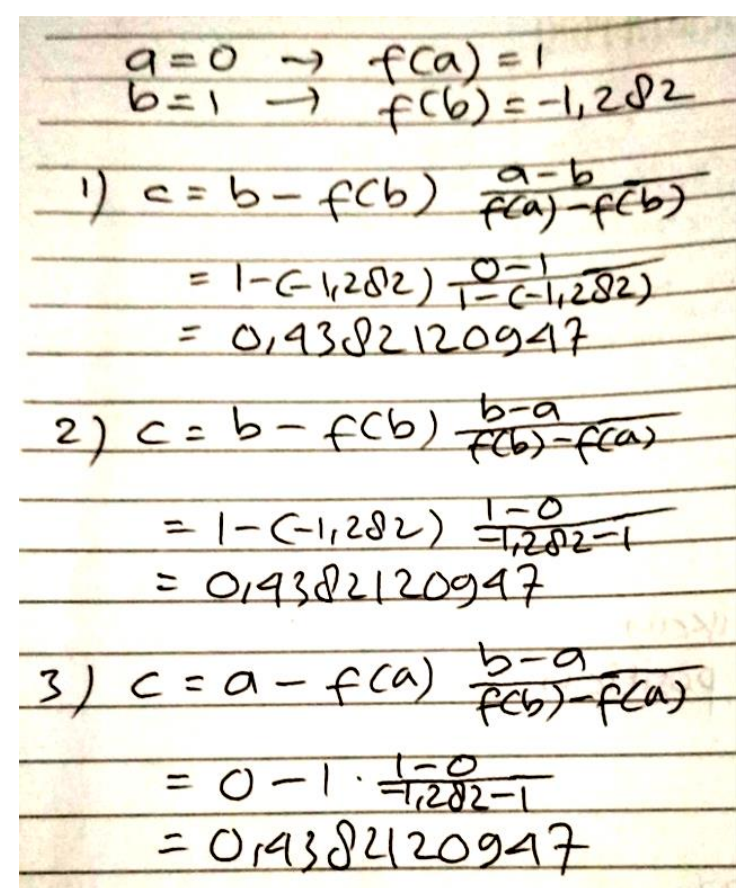

Gambar 7. Hasil Perhitungan MN1 pada Iterasi 1 Soal Nomor 1 dengan Formula/Rumus yang Berbeda-beda

P :Jadi dipahami lagi ya. Yang dipahami itu konsepnya, bukan simbolnya yang dihafalin.

NM1 :Baik Pak.

Berdasarkan script di atas, NM1 pada awalnya mempunyai pemahaman bahwa rumus/formula yang digunakan jika simbolnya berbeda akan menjadi salah. Setelah diberikan satu contoh proses perhitungan yang dapat ditempuh dalam 3 cara, NM1 baru menyadari. Konsep dalam matematika tidak boleh terpaku pada simbol semata, tidak boleh hanya dihafalkan secara simbolik saja.

Sebagai calon guru, pemahaman seperti ini tidak bisa dibenarkan. Itulah sebabnya guru harus terus belajar mengembangkan kompetensinya. Sumber belajar yang tidak terbatas memungkinkan peserta didik mempunyai konsep yang berbeda. Guru harus bisa mengikuti pemahaman peserta didik sehingga bisa mengarahkan pada konsepsi yang benar dan meluruskan jika peserta didik mempunyai konsepsi yang salah. Peserta didik tidak akan berkembang jika pola pikirnya harus sama dengan gurunya.

Data diperoleh dari observasi pada proses pembelajaran di kelas, hasil tes tertulis dan hasil wawancara dengan subjek penelitian (MN1), dapat mendiskripsikan bahwa MN1 memahami simbol baru sebatas prosedural dalam proses perhitungan saja. Hal ini diindikasikan dengan MN1 mengidentikkan penamaan simbol selalu didasarkan pada urutan abjad atau urutan angka. MN1 hanya mengacu pada pengalaman pertama MN1 dalam menerima konsep persamaan garis. Berdasarkan kebiasaan yang telah diterima pada pengalaman sebelumnya, simbol dipahami oleh MN1 sebagai urutan penulisan dalam perhitungan, belum memperhatikan konsep yang mewakili simbol tersebut.

Perulangan simbol pada langkah perhitungan-perhitungan sebelumnya membuat MN1 membuat generalisasi bahwa langkah selanjutnya juga memuat simbol yang sama. MN1 terjebak pada pemahaman prosedur yang dimaknai perulangan perlakuan yang sama. 
Hasil penelitian juga menunjukkan MN1 hanya terpaku pada simbol dalam prosedur perhitungan, sehingga menimbulkan pemahaman konsep yang keliru dalam proses perhitungan itu sendiri. Bukan hanya itu, konsep dasarnya pun menjadi kurang tepat, karena MN1 hanya terpaku pada masalah perhitungannya saja, terlepas dari penggunaan simbolnya.

Salah satu solusinya adalah penerapan strategi perkuliahan kolaboratif berbasis masalah. Berdasarkan penelitian yang relevan [13] bahwa strategi perkuliahan kolaboratif berbasis masalah direkomendasikan untuk diimplementasikan pada perkuliahan mahasiswa calon guru matematika karena diyakini akan dapat mengembangkan kecakapan matematis mahasiswa, baik pemahaman konseptual, kelancaran prosedural, kompetensi strategis, penalaran adaptif, maupun disposisi produktif. Pengembangan kelima komponen kecakapan matematis tersebut dapat dilakukan secara terpadu pada perkuliahan yang menggunakan strategi kolaboratif berbasis masalah, karena dalam setiap langkah pada strategi tersebut memberi peluang untuk berkembangnya kelima kecakapan matematis tersebut.

Sedangkan kepada siswa, guru dapat mengoptimalkan pendekatan PBL (Problem Based Learning). Karena PBL sudah sejalan dengan penerapan kurikulum yang satu rangkaian dengan pendekatan saintifik sebagai landasan dalam proses pembelajaran.

\section{SIMPULAN DAN SARAN}

Simpulan berdasarkan hasil penelitian menunjukan NM1 menginterpretasikan simbol baru sebatas prosedur perhitungan saja. NM1 menganggap, dengan simbol yang sama tetapi berbeda bentuk operasi hitungnya, merupakan suatu kesalahan. NM1 memberikan kesimpulan yang salah akibat dari menuliskan prosedur hanya dilihat dari kesamaan simbol, tidak dilihat dari konsep yang melatar belakangi penggunaan simbol tersebut.

Saran yang peneliti berikan adalah sebagai calon guru hendaknya mahasiswa belajar dengan menekankan pemahaman konsep yang benar, bukan hanya terpaku pada proses perhitungan yang melibatkan simbol-simbol dalam rumus/formula saja. pengembangan kompetensi diri menjadi keharusan. Belajar tidak hanya bersumber dari materi yang disampaikan dosen saja. Guru terhadap peserta didik maupun dosen terhadap mahasiswanya hendaknya menekankan proses pembelajaran yang mengacu pada proses pembentukan konsep, tidak hanya tertuju pada penggunaan simbol-simbol, rumus-rumus dan perhitungannya saja. Guru terhadap peserta didik, dalam proses pembelajaran dapat mengoptimalkan penerapan pendekatan PBL. Sedangkan dosen terhadap mahasiswa, penerapan strategi perkuliahan kolaboratif berbasis masalah dapat menjadi salah satu alternatif solusi.

\section{DAFTAR PUSTAKA}

[1] Widyawati, S., "Pengaruh Kemampuan Koneksi Matematis Siswa terhadap Prestasi Belajar Matematika Ditinjau dari Gaya Belajar pada Materi Bangun Ruang Sisi Datar Siswa Kelas IX SMP di Kota Metro," J. Iqra, vol. 1, no. 1, pp. 47-67, 2016.

[2] ElSheikh, R. M. and Najdi, S. D., "Math Keyboard Symbols and Its Effect in Improving Communication in Math Virtual Classes," Int. J. Inf. Educ. Technol., vol. 3, no. 6, pp. 638-642, 2013.

[3] Maharaj, A., "Some Insights from Research Literature for Teaching and Learning Mathematics," South Afr. J. Educ., vol. 28, no. 3, pp. 401-414, 2008.

[4] Njagi, M.W., "Language Issues on Mathematics Achievement. International Journal of Education and Research," Int. J. Educ. Res., vol. 3, no. 6, pp. 167-178, 2015. 
[5] Yunarni Y, A., Dassa, A., and Asdar, "Profil Pemahaman Notasi Aljabar Ditinjau dari Kemampuan Verbal Siswa di Kelas V Sekolah Dasar,” J. Daya Mat., vol. 3, no. 3, pp. 1-9, 2015.

[6] Akgun, L. and Ozdemir, M.E., 'Students' Understanding of The Variable as General Number and Unknown: A Case Study," Teach. Math., vol. 9, no. 1, pp. 45-51, 2006.

[7] Asnawati, S., Liliana K.D, I., and Muhtarulloh, F., "Penerapan Pembelajaran Inkuiri dengan Etnomatematik pada Materi Bidang Datar terhadap Kemampuan Pemahaman Matematis Siswa," J. Euclid, vol. 2, no. 2, pp. 275-295.

[8] E. F. Ningsih, "PROSES BERPIKIR MAHASISWA DALAM PEMECAHAN MASALAH APLIKASI INTEGRAL DITINJAU DARI KECEMASAN BELAJAR MATEMATIKA (MATH ANXIETY)," Iqra Educ. J., vol. 1, no. 2, pp. 191-217, Mar. 2017.

[9] Groth, R.E., "Situating Qualitative Modes of Inquiry Within The Discipline of Statistics Education Research,” Stat. Educ. Res. J., vol. 9, no. 2, pp. 7-21, 2010.

[10] Sugiyono, Metode Penelitian Kuantitatif, Kualitatif dan R\&D. Bandung: Alfabeta, 2015.

[11] Sharma, S., "Qualitative Approaches in Mathematics Education Research: Challenges and Possible Solutions," Educ. J., vol. 2, no. 2, pp. 50-57, 2013.

[12]Dewi, I., "Profil Keakuratan Komunikasi Matematis Mahasiswa Calon Guru Ditinjau dari Perbedaan Jender," J. Didakt. Mat., vol. 1, no. 2, pp. 1-12, 2014.

[13] Widjajanti, D.B., "Mengembangkan Kecakapan Matematis Mahasiswa Calon Guru Matematika Melalui Strategi Perkuliahan Kolaboratif Berbasis Masalah," presented at the Prosiding Seminar Nasional Penelitian, Pendidikan dan Penerapan MIPA, Fakultas MIPA, Universitas Negeri Yogyakarta, Universitas Negeri Yogyakarta, 2011. 
Numerical: Jurnal Matematika dan Pendidikan Matematika, Vol. 1 No. 2 Desember 2017, 73-86

Fauzi Mulyatna, Wahyu Kusumaningtyas

[Halaman ini sengaja dikosongkan] 